\title{
A Study for Searching New Foundation of Philosophy of Islamic Education to Revitalizing the Teacher Roles and Duties in Globalization Era
}

\author{
H. Akhyak M. Ag
}

\begin{abstract}
The teachers existence to accompany the educational success for students in the era of globalization was very important. Teachers were required to have a strong guide line in performing their duties and roles to accompany the learners in order to have a powerful ability to cope the changing times. Teachers as the one of the main pillars of education needed to have a strong foundation of educational philosophy in order to have the proper and right guidance to develop the vision, mission, and educational action to the learners. The purpose of this study was to search new concept of philosophy of Islamic education foundation for teachers in the era of globalization, through the depth-literature research. This study gave two recommendation: 1) Philosophical concept of new Islamic education philosophy foundation to revitalizing of the implementation of teachers' duties in Islamic education needed to be done systemic, contextual and proportional. 2) Philosophical concept of new Islamic educational philosophy foundation to revitalizing of the implementation of teachers' roles in Islamic education needed to be done professionally Educative and theological-global.
\end{abstract}

Index Terms-New foundation, philosophy of Islamic education, roles and duties of teacher, globalization era.

\section{INTRODUCTION}

Globalization is transforming the culture of the world. The events, policies, and changes, any where in world, influencing the all over the world. The main stake holder of education in globalize world have to adopt the new trends and technique to make their disciples more competent to coop with the new challenges. In globalize Islamic world the role of teacher much important than past [1]. Education is a process whose ideals one never reaches. The most important thing is that there is an attempt to reach that ideal. In the process, one struggles to be self-reliant. This struggle is done in the society in collaboration with other human beings. Hence, learning and getting education is a shared endeavour. Philosophy of education is a discipline that is shared by other disciplines within the human milieu that encompass all experiences, from conception to death, that may be marshalled to make a human being desirable to others and useful to themselves and to the society [2]. Ashraf (1985) defines Islamic education as "an an education which trains the sensibility of pupils in such a manner that in their attitude to life, their actions and decisions and approach to all kinds of knowledge, they are governed by the deeply felt ethical

Manuscript received August 5, 2013; revised October 6, 2013.

H. Akhyak M. Ag is with the STAIN Tulungagung- East Java, Indonesia (e-mail: akhyakyunis@yahoo.co.id). values of Islam" [3].

The teacher's role and responsibilities in education was very hard in the era of globalization. Education had a vital role to develop the science and guide the learners in order to have a holistic intelligence intellectual, emotional, spiritual, and moral and guide them to be useful to themself, society, nation and religion. Teachers as the important actors in the world of education needed to have an extensive knowledge about science and philosophy of education. In Islamic education, Islamic education philosophy had a function to provide the foundation for teachers to perform their duties in order to have a best and right base thinking.

In their study, Wright, Horn and Sanders (1997) concluded that important factor influencing student learning is the teacher. Teachers stand in the interface of the transmission of knowledge, values and skills in the learning process. If the teacher is in effective, students under the teacher's tutelage will achieve in adequate progress academically. This is regardless of how similar or different the students are in terms of individual potential in academic achievement [4]. Teachers play an important role in the success of students. Teachers' self-efficacy has been found to be associated with student motivation, teachers' adoption of innovations, teachers' competence as rated by super intendents, effective classroom management strategies of the teacher, time spent on different subjects, and teachers' referrals of students to special education [5].

Philosophy of Islamic Education provided the opportunity to every educator to get used to conduct the depth reflection on the implementationa of educatian and the education problem and it solutions. By the Islamic education philosophy foundation, educators and teachers were expected to give priority to critical and reflective thinking in settle the problems of life and livelihood, and especially the fundamental problems in education. By this Islamic educational philosophy foundation also, the educators and teachers werealways expected to review the basic view of education philosophy that had been believed were correct [6].

Al-Syaibany explained that the Philosophy of Islamic Education gave the benefit in develop the Islamic education that was: Help the education designers and implementers in forming the right thinking to the educational process; Provide the basic assessment of general and specific education; Become the basis of educational assessment comprehensively; Provide the intellectual prop, guidance for education implementers to face the emerging challenges in the field of education, as the answer to every problem that arised in the field of education; Provide deepening education that had relationship with the factors of spiritual, cultural, 
social, economic, political, and various other life [7].

The philosophy of Islamic education is looking at the principles and concepts underlying education in Islam, it is analyzing and criticizing, deconstructing and disintegrating of the existing educational infrastructure and strives to produce new concepts continuously or displays what should be the concepts. In this sense it is philosophy that beyond what is existing constantly toward absolute values, and is working in the space of Islamic knowledge and who is human and moral essence. The Islamic Education is seeking to achieve the distinct role of the human being which is reform and construction of human life. This Islamic concept of life based on the fundamental concepts as individual, society and the world, and education works to find a balanced relationship and equitable between the parties to this equation which are based on a relationship characterized by a mutual and integration, so one party cannot survive without the other parties [8].

The philosophy of education determines the aims and objectives of education. There are different philosophies of education. Naturally there are different aims and objectives of education. One of the aims and objectives is to transmit the experiences of one generation to another generation. The educationists have emphasized the experiences of the whole society and not experiences of the individual person. Individuals develop several types of beliefs, different forms of opinions, generalize various kinds of principles and publish these experiences in the form of literature. These beliefs, opinions, principles and literature take the shape of experiences of one generation and are transmitted to another generation. This transfer is continuous and nobody feels its transfer easily [9].

Mohd Aliff Mohd Nawi, Ezad Azraai Jamsari, Mohd Isa Hamzah, Adibah Sulaiman and Azizi Umar, had conducted the research by the title, The Impact of Globalization on Current Islamic Education, and published in Australian Journal of Basic and Applied Sciences on 2012. According this research globalization has a huge impact on the world, including Islamic education. The objective of this article is to study the effect of globalization on Islamic education. This study uses the qualitative method, through literature review and document analysis. Research outcome shows three identifiable major effects which are: curriculum transformation, teaching style and method as well as the digital practice of Islamic Education. In conclusion, globalization has a great impact on the world, particularly with the rapid growth and development of information communication technology (ICT). This advancement opens the space and opportunity for Islamic Education to adapt itself to various beneficial mediums in order to achieve the purpose of implementing teaching and learning Islamic Education more effectively [10].

Different with the study above, this study aimed to explore new concepts about the foundations of Islamic education philosophy for teachers in the era of globalization, through the depth-literature research. The research focus was two, there were: 1 .How did the philosophical concept of the New Foundation of Islamic Education philosophy to revitalizing of the implementation of teachers' duties in Islamic education in the era of globalization? 2. How did the philosophical concept of the New Foundation of Islamic Education philosophy to revitalizing of the implementation of teachers' roles in Islamic education in the era of globalization?

\section{RESEARCH METHOD}

This research was so much need a refined literary philosophic and theoretical than empirical testing in the field. Thus, according to the type of this research, the things that need to be mentioned in the methods section of this study was the data source, data collection, and analysis methods.

In this study, there were two kinds of data sources, namely primary data source and secondary data source. What is meant by primary data here are the works or writings on Islamic education thought. Data and sources of this study were from:

1) Results of research on Islamic education

2) Scientific books that written by authors who have an international reputation in philosophy of Islamic education, humanities, social, and Islamic education science.

3) Scientific articles on education, that has published by the international journal or books in high reputation.

4) Consultation/dialog with the experts who have an international reputation in education, humanities, and social science.

Data collected by documentation methods. Sources of data that have been collected, both primary and secondary sources, serve as a document. The documents were then read and interpreted to find the required data in accordance with the formulation of the problems that exist in this study. Each document was read, as long as the groups associated with the data was directly incorporated into each group. All documents read many times and every data found inserted into each group of data. After the necessary data were considered sufficient, then do systematization, while continuing to enrich the data, until data analysis.

The data have been collected and analyzed by the method of analysis language, hermeneutics, and internal coherence. Analyze something was to separate the components and parse matters related to such things. Analysis of the language used to understand and interpret the true meaning of the ideas and opinions were concerned. After analyzing the language, then be followed by a hermeneutic analysis. Hermeneutic studies focused on understanding the problem of understanding of the text. In general, can be defined as a hermeneutic theory of interpretation of meaning. Paul Ricoeur defines hermeneutics as a theory of text interpretation; interpretation process which is based on the content and meaning which seems to the hidden meaning.

\section{THE FOUNDATION OF ISLAMIC EDUCATION PHILOSOPHY ON REVITALIZATION OF TEACHER'S DUTIES}

According Soejono, a good teacher should be qualified were follows: Had a maturity age; Healthy both mental and physical; had the expertise and skills in teaching; had morality and high dedicated [11]. Because a teacher's job was 
then professionaly work, so become a teacher accorded to Hamalik must have the followed requirements: Talent as a teacher; skills as a teacher; a good personality and integrated; a healthy mental, healthy bodied; the wide experience and knowledge. Teachers were the human had Pancasila (Five Principles) spirit, teachers were the good citizen [12]. Teachers must had well morality, if we say "well-behaved", so it contained all the attitudes, character and nature-among other good qualities, Candidates was really talented, Clever in polite language, Good and strong personality, Must liked and respected by learners, Had stabilized emotions, Smart adjust, Not to be sensitive, Should calm, objective, thoughtful, Be honest and fair, Should be decent in behavior, Had large social character [13].

An-Nahlawy stated that Muslim educators properties were as follows:

(1) should the purpose, behaviors and mindsets of teachers/educators were Rabbani; (2) sincerity, which was intend to get the God permission, achieve and uphold the truth; (3 ) patient in teaching a variety of science to students; (4) Be honest in conveying what shouted, in the sense of applying the recommendations to himself firstly, as if science and charity was collateral, so learners would easily imitate him in every words and deeds; (5) maintain and equip themselves with knowledge and willing to assess and develop it; (6) able to use a variety of teaching methods variedly, mastering well, capable on determining and selecting appropriate teaching methods appropriate to the subject matter and teaching-learning situation; (7) capable to manage the learners, resolute in action, and put problems proportionally; (8) studied the psychic life of the students in tune with the future development; (9) responsive to a variety of conditions and the development of the world that affect the life, belief and thinking patterns of learners, understand problems of modern life and how to cope it deal with Islam, and (10) be fair among the learners [14].

According to al Abrasyi, the characters must be possessed by the teacher of Islamic education was as follows: Zuhud not gave priority to material and teaching because seeking for the pleasure of Allah; Cleanliness teacher (Clean body, clean soul, and avoid sin and error); Sincerity in work; Easy forgiving; A teacher was a father before he was a teacher; knowing the students' habit, should holding the subjects [15].

Requirements that needed to be met by teachers in order to attempt the effort well done that was: He must understand the pedagogy as well as possible so that all actions in educating their students appropriate to the soul. He must havea good language and used it as possible. So that it leaded to subtle feelings in children. He must love the students, because love always means eliminating self-interest for other purposes [16].

Teacher assignments in humanities at the school should be able to make themselves as the second parent. He should be able to attract the sympathy so that he became the idol of the students. Every lessons should be a motivation for students to learn. When a teacher in performed was not interesting. The first failure was he would not be able to sow the seeds of his teaching to the students. Education is a very important human activity. It helps any society fashion and model individuals to function well in their environment [17].
Teachers assignment in society was that in society puts teachers on a more prominent place in their environment because of they were expected by society to acquire the knowledge, even the teacher was essentially a strategic component which had an important role in determining the forward movement of the nation, even the existance of a teacher as the main factors which may not be replaced by any component in life of the nation since the first, first-more on this contemporary era.A teacher played an important role in education once of the duties that must be carried out by teachers at the school was to provide service to the students so that they become a student in tune with the school's goals [18].

Islamic Education aims to make Balance between three levels: sense, mind and ethics, and promoting them by various Educational methods. The ego's progress is a continuous dynamic movement which assimilates the different aspects and stages, without negating any, the perceptive and the intellectual, thought and emotions, ideas and deeds are all integrated into the final aim of the ego [19]. Ibn Miskawaih stipulated intellectual, physical and moral education aiming at producing good human beings from the social point of view and achieving eternal happiness and self realization. He presented the view that physical education must precede the spiritual and intellectual education. True education must therefore, minister to the needs of the body no less than the aspirations of the soul [20].

Truly teachers had a great services in accompany human dignity, therefore teachers needed to get the appropriate appreciation fom all parties. Respect for the teacher rather than the demands of the teachers, but it was our duty to do so. In the Muslim community context, teachers should be people who strongly adhere to Islam, not only in appearance but also in their minds. He must be a good and pious, who felt that being the responsibility of them trained the students become good Muslims, the men and women who wanted to study the law of moral values of Islam, who would lived their lives according to the ethic taught at al - Quran, that his deeds would be a role model by young men [21].

Communities placed teachers to honorable place in the society, which gave the models at front, giving spirit at the middle, and give encouragement and motivation behind (Ing Ngarso Sung Tulodho, Ing Madyo Mangun Karso, Tut Wuri Handyani. Such was the position of teachers always relevant to the times and until whenever necessary. Position as it was a tribute by communities do not mean small for teachers, as well as an achievement and a challenge that requires constantly tested achievement and commendable of each teacher. Not only in the classroom and school but also at community levels.

Modern life was moving towards professionalism demanding the position of the teacher as professional job [22]. It also called the professionalism in accordance with the changing demands of society, professional teachers'profession not just a tool for cultural transmission but transform this culture towards a dynamic culture that demands mastery of science, high productivity, and quality of work that can be compete. Professional teacher was no longer a person who serves as a robot but a dynamic factor who drove the learners'potential towards creativity. 
From various views above, remember the times were always changing so in the present era the teachers moreover in the future needed to anticipate changes time by proactive, dynamic, and creative, through the preparation of self-potential of the superior quality and competitive. In the context of globalization, the world has changed drastically on a variety levels, both cultural and economic. The world has become further intertwined through global technology, transnational business, and international trade. Globalization affects daily livelihoods at international, national, and regional levels [23]

Therefore teachers as educators of the generation in the era of globalization needed to revitalize its role in educate students. Related to its revitalization effort, the teachers in Islamic education need to have a foundation of philosophy as follows:

1) In terms of qualifications: teachers needed to have academic eligibility wass not only evidenced by a degree and a diploma, but it must be supported by self-superior quality.

2) In terms of personality, the teachers needed to have a high personality, which was adorned with noble morality in all his behavior.

3) In terms of learning: Teachers needed to understand the theory and practice of science education and its curriculum. Capable designed a good learning programme. Able to implement the learning programs with effective learning art. Capable evaluated the learning potentially. And as the end point theachers were able to accompany the learners in learning successfully.

4) From the social point of view, teachers as educators needed to have social sensitivity to face the social phenomena around them, because teachers one of the elements of society that had different resource quality compared with the other elements of society.

5) In terms of religious, teachers needed to have a high religious commitment, which manifested as a smart and creative in life.

6) In terms of psychological, teachers needed to have the ability to recognize mental development of the children both aspects of intellectual, emotional, and spiritual. Development in proportion to the third aspects of intelligence needed the maximum attention by teachers.

7) In terms of strategy, teachers needed to enrich themselves with a variety of methods, approaches, and techniques of learning which had more reliability accompany the learners in achieving the learning goals.

\section{THE Foundation OF PHILOSOPHY OF ISLAMIC EDUCATION TO REVITALIZING OF TEACHER'S ROLES IN GLOBALIZATION ERA}

\section{A. The Revitalizing of Teacher Roles as Innovator and Motivator}

Educational reform was a new change, and qualitatively different from what existed before and deliberate efforts made to improve the ability to achieve certain goal in education [24].Teachers should had a soul of renewal in order to the education had a quality to accompany the learners looked at their future. To hold the education reform, we should increase the professionalism of teachers. To form the teaching profession, it needed knowledges as a provision of the preparation or carrying out in educational work. The important knowledges to form teacher' profession, was:

1) Knowledge of education, which included theoretical education science and historical education science.

2) Psychological Knowledge.

3) Knowledge of curriculum.

4) Knowledge of teaching methods, e) Knowledge of the basic and educational purposes, f) Knowledge of morals, values and norms [25].

Motivation defined as the complex forces, impulses, needs, tension statements, or other mechanisms that initiate and maintain the desired activities towards the achievement of the objectives [26]. Motivation was a "provocation", a conscious effort to influence the behavior of someone so that by own' motion act to do something as to achieve a particular outcome or goal [27].

Teachers must be able gave motivation, direct motivation either indirect motivation. Because all it would affect the ability of students to increase the interest and achievement in learning. Teachers were important factors that influence the success of the implementation of the curriculum, and even determine the students'success or failure in learning.

Teachers should be able to move the students to always have a high motivation to learn. The motivation, grow and evolve with the direct path of the individual itself (intrinsic) and comes from the environment (extrinsic) [28].

In relation with motivation, teachers should be able to raise the motivation of learners, with regarded to the principles were: Learners will work hard if you have the interest and attention to his work; Provide a clear task and it is understandable; Tribute to the work and achievements of learners; Using rewards and punishments effectively and efficiently.

Learning from the experiences, in learning the conditions were not much different means students have the curiosity, and they have the potential to satisfy their curiosity. Therefore, the most important concern of teachers was how to conduct a fun learning environment, in order to arouse the curiosity of all learners so that the growing interest and desire to learn.

Rachmer and Martin (2001) examined seven personality traits: extraversion, approachable, outgoing, establishing a caring, loving and warm atmosphere with students, have a sound knowledge of subject matter, take a personal interest in each student, and enthusiastic personality with a sense of humor and 8 items reflecting teaching effectiveness. The findings indicated that effective teachers display extraverted traits, approachable, enthusiastic, and outgoing with a sense of humor. [29].

\section{B. The Revitalizing of Teachers Duties as an Educator and Instructor}

Teacher's job was not merely "teaching", but also had to do a variety of things that had to do with education students [30]. In this case the teachers' role there were two kinds, they were teachers as educators and teachers as instructors. Teaching 
learning process or learning helped students develop the intellectual potential to them. [31] Education was an effort to help an adult yet to reach maturity [32]. Teaching was delivered knowledge or science from a teacher to students [33]. Njoroge and Bennaars (1986)) define education as "the inter-subjective process of learning to be a self-reliant person in society" [34].

Educate deeds called as a beautifully art activity because it should be based on educational activities of humanity, sympathy, and love, with the love of the education job duties as a dharma or a noble mission of life, accompanied by a sincere love. In his role as manager of classroom teachers should be able to manage the classroom as a learning environment and as an aspect of the school environment that need to be organized. It regulated and supervised environment for learning activities focused on the purpose of education. Supervision of the learning environment helped to determine how the environment became a good learning environment. Good environment were challenging and stimulating the students to learn, provide a sense of security and satisfaction in achieving the goals [35]. Teachers are also school managers who manage their students in and out the classroom. Thus, curricular and co-curricular activities must be planned and executed effectively to ensure students' holistic development [36].

Relating to the teacher's role as an educator, the teacher should have sufficient knowledge and understanding of education media because it was communication media in order to activate the teaching learning process, with thus education media was a basic what needed complementary and as an integral part for the success of the process education and teaching in schools. Besides that, teachers should be able to seek the useful learning resources as well as to support the achievement of the objectives and teaching learning process, both in the form of a resource, text books, magazines, or newspapers.

Relating to the role of the teacher as the educator, teacher should always mastery the material. They were chose from a range of scientific, common levels and in accordance with the students; so the duties included study the students' psychology and have a perfect knowledge/ full of teaching sciences, especially those taught to students, made it easy delivery to the students in a sequence, systematic, harmonious and related to each other.

The ways of teaching process can reflect how a philosophy influences its people through education system. From the view of Western education philosophy, the roles of students are recognized, by giving them the rights and respects within the teaching and learning process itself. They have the freedom and rights to take charge of their own learning, as they are given the opportunity and freedom to manage their own learning process. Therefore, the teachers play their role as a facilitator than the knowledge producer to their students. Teachers are responsible to help and guide the students in their learning process rather than teaching them what to do. In this way, students are given the opportunity to take control of their own learning process [37].

For Al-Ghazali, the purpose of society is to apply shari ' $a$, and the goal of man is to achieve happiness close to God. Therefore, the aim of education is to cultivate man so that he abides by the teachings of religion, and is hence assured of salvation and happiness in the eternal life hereafter. Other worldly goals, such as the pursuit of wealth, social standing or power, and even the love of knowledge, are illusory, since they relate to the transient world. Education is not limited to training the mind and filling it with information, but involves all aspects - intellectual, religious, moral and physical-of the personality of the learner. It is not enough to impart theoretical learning; that learning must be put into practice. True learning is that which affects behaviour and whereby the learner makes practical use of his knowledge [38].

According to Al-Attas (1980) education can be defined as "Recognition and acknowledgement, progressively instilled into man, of the proper places of things in the order of creation, such that it leads to the recognition and acknowledgement of the proper place of God in the order of being and existence [39]. According to Ashraf (1985) the aim of education according to the ummah in general, is to produce a good Muslim who is both cultured and expert; .cultured in the sense that he knows how to use knowledge for his spiritual, intellectual, and material progress, and expert in the sense that he is a useful member of the community. The philosophy of general education which is the prevalent system of education in Muslim countries is incomplete as mentioned earlier because it leaves out one aspect of human personality, its spirit. [40]

The aims and objectives of Islamic Education in Contemporary Perspectives, Mohd Sharif Khan (1986) stated in his book that the aims and objectives of Islamic education may be as follows: To provide the teachings of Holy Quran as the first step of education. To provide experiences which are based on fundamentals of Islam as embodied in Holy Quran and Sunah which cannot be changed. To provide experiences in the form of knowledge and skills. These experiences are likely to be changed in the light of changes in society. To develop understanding that knowledge without the basis in faith and religion is in complete education. To develop commitment towards the basic values which have been prescribed in religion and scripture? To develop the sense of accountability towards Almighty Creator so that man passes his life as a faithful servant. To develop piety and faith among the followers. To develop such qualities of a good man which are universally accepted by the societies which have faith in religion. To encourage international brotherhood irrespective of differences in generations, occupations, and social class amongs the person who are knit together by a common religion and faith. To foster great consciousness of the Divine Presence in the universe. To bring man nearer to an understanding of God and of the relation in which man stands to his creator. To produce man who has faith as well as knowledge in spiritual development [40].

Teachers as educators in the era of globalization needed to concentrate on educate the children and prepared them as well as possible, in order they had the perfect personality, so the teacher must be an educator who served to educate the body, mind, and morals, by a perfect education with the various method and approaches.

Teacher's duties was not only conveyed the knowledge and fill their minds with science, but the duty to guide students to be adults. Then he responsible for strengthening student body, 
foster their understanding of what was taught to him from various sciences, in forming their minds, fostering moral, helping in the search knowledge, arouse love (passion) to provide the studentsspiritual food, and instilled in the soul, noble character and make a good custom.

\section{RECOEMENDATION}

1) Philosophical concept of new philosophy of Islamic education foundation to revitalizing on implementation of teachers' duties in Islamic education needed to be done systemic, contextual and proportional.

2) Philosophical concept of new philosophy of Islamic education foundation to revitalizing on revitalizing on implementation of teachers' roles in Islamic education needed to be done professionally-Educative and theological-global.

\section{REFERENCES}

[1] M. A. Malik, H. D. Aslam, Z. A. Malik, and R. S. M. Akbar, "Cultural transformation \& classroom management: Demanding role of Muslim teacher in era of globalization," International Journal of Social Sciences and Education, vol. 1, pp. 113, April 2011.

[2] A. K. K. Odhiambo, "Women's contributions to the philosophy of education: Hermeneutics of proverbs," International Journal of Education and Research, vol. 1, no. 3, pp. 2, March 2013.

[3] S. A. Ashraf, New Horizons in Muslim Education, Cambridge: Hodder and Stoughton, the Islamic Academy, 1985, pp. 24.

[4] S. P. Wright, S. P. Horn, and W. C. Sanders, "Teacher and classroom context effects on student achievement: implications for teacher evaluation," Journal of Personnel Evaluation in Education, vol. 11, pp 57-67, 1997.

[5] A. W. Hoy, "Changes in teacher efficacy during the early years of teaching," Paper presented at the annual meeting of the American Educational Research Association, April 2000, New Orleans, L. A.

[6] H. A. A. Saifullah, Antara Filsafat dan Pendidikan, Pengantar filsafat, Surabaya: Nasional, pp. 140 .

[7] O. M. T. Syaibani, Filsafat Al-Tarbiyah Al -Islamiyah, terjemahan Hasan langgulung, Filsafat Pendidikan Islam, Jakarta: Bulan bintang, 1979, pp. 33-36.

[8] S. Rayan. "Islamic philosophy of education," International Journal of Humanities and Social Science, vol. 2, no. 19, pp. 150, October 2012.

[9] M. H. K. Hafiz and M. J. Salleh, "The Philosophy and Objectives of Education in Islam," Prosiding International Islamic University Malaysia (IIUM)

[10] M. A. M. Nawi, E. A. Jamsari, M. I. Hamzah, A. Sulaiman, and A. Umar, "The impact of globalization on current islamic education," Australian Journal of Basic and Applied Sciences, vol. 6, no. 8, pp. 74-78, 2012.

[11] Soejono, Pendahuluan Ilmu Pendidikan Umum, Bandung: CV Ilmu, 1982, pp. 63-65.

[12] O. Hamalik, Proses belajar Mengajar, Jakarta: Bumi Aksara, 1994, pp. 118.

[13] S. I. Barnadib, Pengantar Ilmu Pendidikan Sistematis, Yogyakarta: Andi Offset, 1982, pp. 73.

[14] A. Nahlawi, Tarbiyah Al Islamiyah wa Asalibuha fi al Bayt wa AI Madrasah Wa Al Mujtama', Darnaskus: Dar Al Fikr, 1979.

[15] Abrasyi, at-Tarbiyah al-Islamiyah wa Falaisatuha, Kairo: Isa al-Babi al-Halabi, 1975, Cet. 3, pp. 136-139.

[16] I. Hamdani, Filsafat Pendidikan Islam, Bandung: Penerbit CV. Pustaka Setia, pp. 102.

[17] G. N. Kimani, A. M. Kara, and L. W. Njagi, "Teacher factors influencing student' academic achievement in secondary school in Nyandarua country," International Journal of Education and Research, vol. 1, no. 3, pp. 1, 2013.

[18] O. Hamalik, Psikologi Belajar dan Mengajar, Bandung: Sinar Baru. Algensindo, pp. 35.

[19] M. Ahmad, Islamic Rationalism in the Subcontinent, Lahore, 1984. pp. 282.
[20] S. M. Z. Alavi, Muslims Educational Thought in the middle Ages, New Delhi: Atlantic, 1981, pp. 35.

[21] S. S. H. dan S. A. Asharaf, Menyongsong Keruntuhan Pendidikan Islam, Terj. Rahmani Astuti, Bandung: CV. Gema Risalah Press, 1994, pp. 158.

[22] Tilar, Membenahi Pendidikan Nasional, Jakarta: Rineka Cipta, 2002, pp. 92.

[23] R. Y. Saenz, "Perspective on the role of education in second-generation immigrants," International Journal of Social Science and Humanity, vol. 2, no. 3, pp. 767-782, May 2012.

[24] C. Wijaya, D. Djadjuri, and A. T. Rusyan, Upaya Pembaharuan Dalam Pendidikan Dan Pengajaran, Bandung: PT Remaja Rosdakarya, Bandung, 1992, pp. 6

[25] A. D. Indrakusuma, Pengantar Ilmu Pendidikan, Malang, Penerbit IKIP Malang, 1973, pp. 176-177.

[26] W. K. Hoy and C. G. Miskel, Educational Administration: Theory, Research, and Practice, New York: Random House, 1982, pp. 137.

[27] N. Purwanto, Psikology Pendidikan, Bandung: PT. Rosdakarya, 1994, pp. 71.

[28] A. S. Makmun, Psikologi Kependidikan, Bandung: Remaja Rosda Kerya, 2003, pp. 37.

[29] S. A. Radmacher and D. J. Martin, "Identifying significant predictors of student evaluations of faculty through hierarchical regression analysis," The Journal of Psychology, vol. 135, no. 3, pp. 259, 2001

[30] E. Mulyasa, Kurikulum Berbasis Kompetensi, Bandung: PT. Remaja Rosdakarya, 2002, pp. 186.

[31] Z. Darodjat, Metodik Khusus Pengajaran Agama Islam, Jakarta: Bumi Aksara, 2001, pp. 262.

[32] I. Barnadib, Beberapa Hal Tentang Pendidikan, Yogyakarta: Penerbit Studying, 1982, pp. 17.

[33] Engkoswara, Dasar-Dasar Metodologi Pengajaran, Jakarta: Bumi Aksara, 1988, pp. 1.

[34] R. J. Njoroge and G. A. Bennaars, Philosophy and Education in Africa, Nairobi: Trans Africa Press, 1986, pp. 244.

[35] K. Kartono, Penganttar Ilmu Mendidik Teoritis, Bandung: Mandar Maju, 1992, pp. 25.

[36] A. A. Rashid and S. Bokkasam. (2004). Teachers' perception on the effectiveness of co-curricular activities: A case study of Malaysian schools. UNITAR E-Journal. [Online]. 1(1). Available: http://ejournal.unitar.edu.my/articles/abdrashid.pdf.

[37] A. Hassan, "Viewing the philosophy of education from the perspectives of different schools of thought," International Review of Social Sciences and Humanities, vol. 1, no. 2, 2011, pp. 47.

[38] Ghazali, Ihya al Ulumuddin.

[39] Attas and S. M. Naqiub, The Concept of Education in Islam: A Framework for an Islamic Philosophy of Education, Kuala Lumpur: Muslim Youth Movement of Malaysia (ABIM), 1980.

[40] S. A. Ashraf, New Horizons in Muslim Education, Cambridge: Hodder and Stoughton, The Islamic Academy, 1985, pp. 39.

[41] M. S. Khan, Islamic Education, New Delhi: Anish Publishing House, 1986.

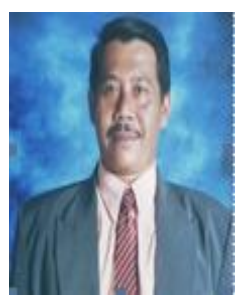

H. Akhyak M. Ag was born in Tulungagung, East Java, Indonesia on October, 29 1967. He obtained his Doctor Degree in Islamic Studies in 2009 from the Doctor Program of Post Graduate of State Islamic University (UIN) Sunan Kalijaga YogyakartaIndonesia. His Dissertation is entitled "The Reconstruction of Islamic Educational Anthropology (Study of Iqbal Thought and its Relevance to Islamic Education in Indonesia). $\mathrm{He}$ is a Lecturer in Islamic Education Department of State Islamic University (STAIN) of Tulungagung, East Java, Indonesia and Pangeran Diponegoro Islamic University (STAI) of Nganjuk, East Java Indonesia. He is also lecturer of Philosophy of Islamic Education in Post Graduate of State Islamic University (STAIN) of Tulungagung, East Java, Indonesia and Post Graduate of Diponegoro Islamic University (STAI) of Tulungagung, East Java Indonesia. He is an assessor of the National Higher Education Accreditation Council (BAN-PT) (2009Now). He is also The Chairman of Expert Council of Nahdlatul Ulama Scholars Association (ISNU) of Tulungagung, East Java Indonesia.. Some of his Published Books are: The Innovation of Islamic Education, The Profile of Successful Teacher, toward Islamic Education based Ethics, and Philosophy of Islamic education. His current research interest is in Islamic Education. He is also a senior member NO.: 13008047 of the International Economics Development Research Center (IEDRC). 